\title{
Factors Remaining Business Results on the Quality of Savings and Loan Cooperative Financing in Subang Regency
}

\author{
R. Susanto Hendiarto ${ }^{1}$, Vincentia Wahju Widajatun ${ }^{2}$ \\ ${ }^{1,2}$ Universtas Widyatama \\ Email: r.susanto@widyatama.ac.id
}

(Received: January 10-2020; revised: February 13-2020; published: June 30-2020)

\begin{abstract}
Profit is not the main goal of the cooperative business, but the business that is managed by the cooperative must obtain the remaining business results that are feasible so that the cooperative can maintain its survival and improve the ability of its business. This study aims to determine the effect of the number of members, own capital, external capital, business valves, and assets owned to the remaining results of business (Indonesian terms: Sisa Hasil Usaha/SHU) savings and loan cooperatives in Subang district. The sampling technique used was purposive sampling so as many as 14 cooperatives were selected. Data analysis used in this study is classical assumption analysis and then panel data analysis is carried out, determination of test coefficients (R2), F statistical tests, $t$ statistical tests. Based on the results of research that has been carried out simultaneously known all independent variables significantly influence the residual business results. However, the partial test shows that only the variables of business capital, business volume, and assets owned by cooperatives have an effect on the residual results of operations, while the variable number of members and external capital has no effect on the residual results of operations.
\end{abstract}

Keywords: own capital; external capital; business volume; cooperative assets

\section{INTRODUCTION}

Indonesian cooperatives began in the 20th century which were generally the result of efforts that were not spontaneous and were not carried out by very wealthy people (Asril \& Syah, 2015; Heriyono, 2012; Nanga, 2001). Cooperatives grow among the people, when the suffering in the economic and social fields caused by the capitalism system is increasingly mounting. Some people whose livelihoods are simple with limited economic capacity, driven by the same suffering and economic burden, spontaneously unite themselves to help themselves and their fellow humans (Ismail, et.all, 2016).

Cooperative business is a business that is directly related to the interests of members to improve the business and welfare of members (Nainggolan, Parulian, \& Siregar, 2016; Sitio \& Tamba, 2001). Other business units run by cooperatives in general are the sale and lending of members' basic needs. Therefore, one way to improve the business and welfare of its members is by providing loans or loans to members who need economic assistance or for additional business (Corie May Hellyana, 2013; Hendar, 2013; Susilowati \& Maudi, 2018). The role of cooperatives in the development of Indonesia is one of the providers of employment in the economic sector. In addition, the role of cooperatives also greatly supports the development of 
54 Jurnal Ilmiah Ilmu Administrasi Publik: Jurnal Pemikiran dan Penelitian Administrasi Publik Volume 10 Number 1, January- june 2020. Page 53-62

development activities, both in the field of economic development and in other fields (Diahastuti, 2011; Fatimah \& Darna, 2011; Wardani, 2013).

In achieving its objectives, cooperatives must pay attention to the management of the accounting system related to all sorts of activities. In the accounting system there is the design of accounting information needed by management and other users, and the design of an information management system to produce accounting information. Therefore, with a good accounting system can produce useful accounting information. In the modern era like now, copersi need an information system in the form of reports that are appropriate and can be accessed at any time in order to find out its development (Farisanu, 2017; Samuda, 2016).

In small cities and cities that are still developing by becoming members of cooperatives is considered as an alternative to meet their economic needs, therefore by becoming a member of the cooperative many benefits are obtained, one of which is that members will get Remaining Business Results (SHU). The cooperative does not use the term profit or profit to indicate the difference between the income received during a certain period and the sacrifice incurred to obtain that income, this difference in the cooperative is called the Remaining Operations (SHU).

According to (Law No. 25 of 1992, 1992), Remaining Results of Operations (SHU) is the income of cooperatives obtained in one fiscal year minus costs, depreciation and other obligations including taxes in the relevant fiscal year, the good residual income is the residual results businesses that are increasing every year. However, the savings and loan cooperatives (KSP) in the Subang Regency Office in 2015/2016 up to 2017/2018 experienced a decline and in 2018/2019 only increased but still small.

The following is the graph of the remaining business results (SHU) of savings and loan credit cooperatives (KSP) from 14 cooperatives found in the performance of subang district cooperatives.

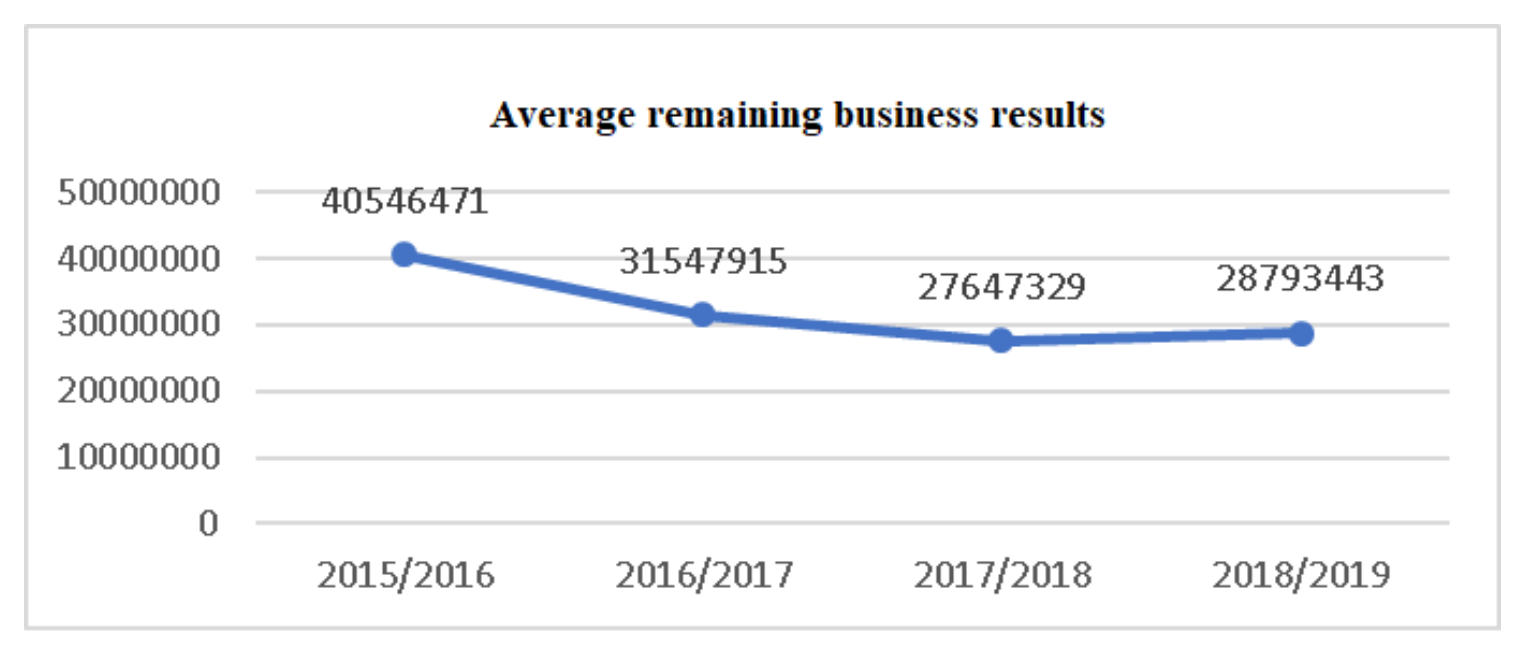

Source: Cooperative Performance Report

Figure 1.

Remaining Operating Results 
Figure 1 shows that the decrease in operating income in 2016/2017 decreased by $0.778 \%$ and in $2017 / 2018$ also decreased again by $0.876 \%$, then only increased the residual income in $2018 / 2019$ by $1.041 \%$. \% , So that it can be concluded the remaining operating results in 2015/2016 until 2017/2018 have decreased and in the following years have increased.

Increased residual business results of a cooperative is very dependent on the activities carried out, in terms of financial aspects of income (SHU) will be implemented if the cooperative is available with sufficient capital. The role of capital in the company's operations has a very important contribution because without sufficient capital, a business will not run smoothly. In the distribution of cooperative venture capital consists of own capital consisting of own capital and loan capital. Own capital can come from principal savings, mandatory savings, reserve savings and other savings, while loan capital comes from members, other cooperatives, banks, other financial institutions, bond issuers and other debt securities. In the management of capital or finance, the cooperative must be able to allocate financial resources owned efficiently to increase profits or often referred to as residual operating results (SHU).

Based on the background description of the problem, the formulation of the problem in this study is How the number of members, own capital, external capital, business volume and assets affect the Remaining Business Results (SHU) of the Subang District savings and loan cooperative. The purpose of this study was to determine and analyze the effect of the number of members, own capital, external capital, business volume and assets on the Remaining Results of Business (SHU) savings and loan cooperatives in Subang Regency. Benefits of Research Benefits of research for the treasury of science is expected that this research can contribute and benefit in the development of cooperatives, especially the problem of Remaining Business Results (SHU). The practical benefits of this research are expected to be beneficial in contributing ideas for Subang Regency savings and loan cooperatives to increase the Remaining Business Results (SHU) and as a consideration for cooperatives in developing strategies to improve and develop other businesses.

\section{METHOD}

The research method is the way or path taken in connection with the research conducted, which has systematic steps. According to (Sugiyono, 2017) the definition of a research method is scientific to obtain data with specific purposes and uses. The research method was designed through research steps starting from operational variables, determining the types and sources of data, data collection methods, and ending with designing data analysis and hypothesis testing. The research method used in this study is descriptive using secondary data, namely data on Cooperative financial statements in the city of Denpasar for the period of 2017 - 2019, obtained from the Subang Regency Cooperative Service.

The population in this study were all savings and loan cooperatives that were recorded as still active in the Subang District Cooperative Service in the amount of 35. The sampling technique used was purposive sampling so that 14 research samples were selected using the Slovin formula in (Sugiyono, 2010) purposive sampling was a sampling technique data sources with certain considerations. The reason for using the Purposive Sampling technique is that not all samples have criteria that fit the phenomenon under study. Therefore, the authors chose the Purposive Sampling technique which sets out certain considerations or criteria that must be met by the samples used in this study. The data analysis technique used in this study is multiple 
56 Jurnal Ilmiah Ilmu Administrasi Publik: Jurnal Pemikiran dan Penelitian Administrasi Publik
Volume 10 Number 1, January- june 2020. Page $53^{-62}$

linear regression analysis.

The data were analyzed using multiple linear regression analysis with SPSS program tools. Before testing the hypothesis, a classic assumption test is performed, namely the normality test, the multicollinearity test, the autocorrelation test and the heteroscedasticity test. To test the hypothesis in this study used a statistical test tool, with the F test and test. The research variables that will be examined in this study are divided into two main variables, namely the independent variable (X) which consists of five variables, namely the number of members, own capital, external capital, business volume, and cooperative assets. While the dependent variable $(\mathrm{Y})$ consists of one variable, namely the Remaining Operating Results (SHU) which is the income earned in one year less depreciation and expenses from the relevant financial year.

\section{RESULT AND DISCUSSION}

Panel data regression analysis was performed to determine the effect of the variable number of members (X1), own capital (X2), external capital (X3), business volume (X4) and assets (X5) on the remaining business results (Y). Panel parameter regression model estimates are performed on three types of model specifications, including the Common Effect Model (CEM), Fixed Effect Model (FEM), and Random Effect Model (REM). After conducting the Lagrange Multiplier (LM) test, the Chow test and the Hausman test that were used for this study were the Common Effect Model (CEM). Panel data regression test results can be seen in table 1 .

\section{Table 1}

\section{Panel Data Regression Test Results}

Dependent Variable: Y

Method: Panel Least Squares

Date: 26/02/20 Time: 10:25

Sample: 20172019

Periods included: 3

Cross-sections included: 14

Total panel (balanced) observations: 42

\begin{tabular}{lllll}
\hline \hline Variable & Coefficient & Std. Error & t-Statistic & Prob. \\
\hline \hline $\mathrm{C}$ & 0.205600 & 60.52840 & 0.049846 & 0.0002 \\
$\mathrm{X} 1$ & 0.046960 & 0.015700 & 1.271900 & 0.0756 \\
$\mathrm{X} 2$ & 3.871074 & 0.307678 & 0.381912 & 0.0007 \\
$\mathrm{X} 3$ & 0.052004 & 0.016310 & 0.217420 & 0.0695 \\
$\mathrm{X} 4$ & 6.089129 & 1.050675 & 0.618329 & 0.0203 \\
$\mathrm{X} 5$ & 0.947070 & 0.056221 & 1.509274 & 0.0129 \\
\hline \hline
\end{tabular}

Cross-section fixed (dummy variables) 


\begin{tabular}{llll}
\hline \hline R-squared & 0.825910 & Mean dependent var & 1.105250 \\
Adjusted R-squared & 0.746519 & S.D. dependent var & 0.293920 \\
S.E. of regression & 0.259288 & Akaike info criterion & 0.058430 \\
Sum squared resid & 0.559202 & Schwarz criterion & 0.452901 \\
Log likelihood & 7.580411 & Hannan-Quinn criter. & 0.002639 \\
F-statistic & 3.832017 & Durbin-Watson stat & 1.637692 \\
Prob(F-statistic) & 0.002504 & & \\
\hline
\end{tabular}

By using a statistical analysis tool in the form of Eviews 9.0, it is known that the regression equation formed is as follows:

$\mathrm{Y}=0.205600+0.046960 \mathrm{X} 1+3.871074 \mathrm{X} 2+0.052004 \mathrm{X} 3+6.089129 \mathrm{X} 4+0.947070 \mathrm{X} 5$

Based on the results of tests that have been carried out, it is known that the constant value of 0.205600 states that if the variable number of members (X1), own capital (X2), external capital (X3), business volume (X4) and assets (X5) equals zero and no changes, the remaining business results $(\mathrm{Y})$ of 0.205600 . The regression coefficient value of the number of members (X1) is positive at 0.046960 , which means that every 1 unit increase in the number of members, it will increase the remaining business results (Y) by 0.046960 units. The regression coefficient value of own capital (X2) has a positive sign of 3.871074, which means that every increase of 1 unit of own capital, it will increase the remaining operating results (Y) of 3.871074 units. The regression coefficient of external capital (X3) is positive with a value of 0.052004 , which means that each increase of 1 unit of external capital will increase the remaining operating results $(\mathrm{Y})$ by 0.052004 units. The regression coefficient value of business volume (X4) has a positive sign of 6.089129, which means that every increase of 1 unit of business volume, it will increase the remaining business results (Y) of 6,089129 units. The regression coefficient value of the asset (X5) has a positive sign of 0.947070 , which means that each increase of 1 unit of asset will increase the remaining results of operations $(\mathrm{Y})$ of 0.947070 .

\section{Influence of Variable Number of Members (X1), Own Capital (X2), External Capital (X3), Business Volume (X4) and Assets (X5) on the Remaining Operating Results (Y)}

Based on the results of simultaneous testing, it is known that together there is a significant relationship between the variable number of members (X1), own capital (X2), external capital (X3), business volume (X4) and assets (X5) to the remaining operating results $(\mathrm{Y})$. The magnitude of the influence of all the independent variables is $82.59 \%$. These results prove that if all elements incorporated in a cooperative are able to implement and control the variable number of members, their own capital, external capital, business volume and assets, there will be an increase in the results of the cooperative's business. The cooperative to always control and encourage its members to actively participate in the success of the programs that have been made. Cooperatives must be able to generate or raise their own capital from members and from grants to the maximum, if using outside capital it must be calculated carefully so that the principal loan and interest payments that are borne by the cooperative can be paid in timely manner. The cooperative must also increase the business activities that are currently carried out, because with this increase can increase the remaining business results, as well as the assets owned. Cooperatives that have assets will have the ability to better serve the needs of members. The results of this study support previous studies conducted by (Sudaryanti, 2017) 
58 Jurnal Ilmiah Ilmu Administrasi Publik: Jurnal Pemikiran dan Penelitian Administrasi Publik
Volume 10 Number 1, January- june 2020. Page 53-62

simultaneously the number of members, external capital, and total assets affect the remaining business results. (Rohmansyah \& Sudarijati, 2017) the results of the F test study explained that joint capital and loan capital together had a positive and significant effect on the remaining business results. (Rohmansyah \& Sudarijati, 2017) business capital, number of members, business volume, and assets together have a significant effect on SHU.

\section{Effect of Variable Number of Members (X1) on Remaining Operating Results (Y)}

Based on the results of partial testing it is known that there is no significant relationship between the number of members (X1) to the rest of the results of operations (Y). The test results suggest that the number of cooperative members in this study had no influence or was not followed by increased profits. Cooperative members are indeed the backbone of the cooperative business but the increase in the number of members who are not accompanied by an active role to save capital, borrow, pay in installments, will not be able to increase the remaining business results. In other words, members are passive and do not participate in developing cooperatives. So from the results of this praise it is important for the cooperative to always control and encourage its members to actively participate, so that the profits, hereinafter referred to as the remaining operating results, can be increased. The results of this study are in line with previous research conducted by (Sudaryanti, 2017; Yuliastuti \& Arie, 2018) which states that the capital itself has a positive and significant effect on the remaining business results. The results of this study are not supported by research conducted by (Cahyani, Zukhri, \& Meitriana, 2016; Dewik \& Jember, 2016; Raidayani, Muhammad, \& Faisal, 2016; Tifani, Surdi Djatikusuma, \& Yunita, 2015) which states that their own capital is not affect the remaining business results.

\section{The Influence of Variable Foreign Capital (X3) on Remaining Operating Results (Y)}

Based on the results of partial testing it is known that there is no significant relationship between external capital (X3) to the rest of the results of operations (Y). External capital is capital that comes from third party loans and is certainly burdened with interest that must be paid. The increase in the amount of outside capital in this study proves not to result in an increase in the remaining amount of cooperative business results. Inefficient use of external capital will increase operating expenses and a bigger problem will be the impact on the poor financial condition due to interest expense and debt installments that must be paid, thus reducing the remaining operating results. The results of this study support previous research conducted by (Hosekini, 2015; Rohmansyah \& Sudarijati, 2017; Yuliastuti \& Arie, 2018) which shows that external capital has no effect on the rest of the cooperative business results.

\section{Effect of Business Volume Variable (X4) on Remaining Operating Results (Y)}

Based on the partial test results it is also known that there is a significant relationship between the volume of business (X4) to the rest of the results of operations (Y), the variable volume of business has a positive and significant effect on the rest of the results of operations. The volume of cooperative businesses is the accumulation of the value of goods and services received from the beginning of the financial year to the end of the financial year. The economic 
activity of cooperatives can be seen in essence from the large volume of cooperative efforts. This research empirically proves that the increase in residual business results that are a source of profit for cooperatives can increase if there is an increase in business volume. To create an increase in the volume of cooperative business can be done if sufficient capital is available and of course managed properly, both coming from member savings and outside capital (debt). The results of this study support previous research conducted by (Hosekini, 2015; Wiyono, 2016; Yuliastuti \& Arie, 2018) business volume has a significant positive effect on the residual results of cooperative business. While other studies conducted by (Putri, Sunarko, \& Widuri, 2016) concluded that the volume of business did not have a significant positive effect on the residual results of cooperative efforts.

\section{Effect of Asset Variables (X5) on Remaining Operating Results (Y)}

Based on the partial test results it is also known that there is a significant relationship between assets (X5) to the remaining operating results (Y), the asset variable has a positive and significant effect on the remaining operating results. Assets are all assets belonging to a company, whether in the form of objects or power of attorney which is obtained from an event that happened in the past and is intended to be a benefit in the future. Cooperatives that have assets in this study prove that they will have the ability to better serve the needs of members. Adding total assets to savings and loan cooperatives will provide more opportunities for cooperatives to channel more loans. Furthermore, assets owned by cooperatives can also reduce operational costs and other costs. If the needs of members can be met properly, the members will become loyal and it means that the income of the cooperative will also increase, so that the remaining business results obtained will also increase. This study is in accordance with research conducted by (Raidayani et al., 2016; Yuliastuti \& Arie, 2018) showing that assets have a positive effect on the residual income of a cooperative.

\section{CONCLUSION}

This study aims to determine how the Factors - Remaining Business Results (SHU) Against the Quality of Savings and Loan Cooperative Financing Subang Regency. Based on the results of research that has been done as for the conclusions obtained are simultaneously or together - together all independent variables namely the variable number of members (X1), own capital (X2), external capital (X3), business volume (X4) and assets (X5) has an influence on the residual results of operations (Y). The magnitude of the influence of the independent variables on the dependent variable in this study amounted to $82.59 \%$, while the remaining $17.41 \%$ was influenced by other variables outside this study. Next, a partial test is performed to find out how the influence of each independent variable on the dependent variable. The partial test results concluded that of the five independent variables, there were only three variables which had a partial effect on the dependent variable. The three variables consist of own capital (X2), business volume (X4) and assets (X5). While the other two independent variables, namely the number of members (X1) and external capital (X3), this study shows the opposite or has no partial effect. 
60 Jurnal Ilmiah Ilmu Administrasi Publik: Jurnal Pemikiran dan Penelitian Administrasi Publik Volume 10 Number 1, January- june 2020. Page 53-62

\section{REFERENCES}

Asril, A., \& Syah, A. (2015). Strategi Pengembangan Koperasi dan Usaha Kecil Menengah (UKM) di Provinsi Riau. Jurnal Ekonomi, Manajemen dan Akuntansi.

Cahyani, M. T., Zukhri, A., \& Meitriana, M. A. (2016). Pengaruh Jumlah Anggota terhadap Perolehan Sisa Hasil Usaha melalui Partisipasi Anggota sebagai Variabel Intervening pada Koperasi Simpan Pinjam Wisuda Guna Raharja Denpasar tahun 2012-2014. Jurnal Pendidikan Ekonomi Undiksha, 5(1).

Corie Mei Hellyana. (2013). Peningkatan Kualitas Pelayanan Koperasi Simpan Pinjam Melalui Knowledge Management System. Bianglala Informatika.

Dewik, N. K. S., \& Jember, I. M. (2016). Faktor-Faktor yang Mempengaruhi Sisa Hasil Usaha (SHU) Koperasi Simpan Pinjam (KSP) di Kecamatan Kuta Utara Kabupaten Badung. EJurnal Ekonomi Pembangunan Universitas Udayana, 5(7), 729-753.

Diahastuti, R. (2011). Peranan Koperasi dalam Meningkatkan Kesejahteraan Masyarakat di sekitar Pondok Pesantren Assalaam. In Skripsi Jurusan Sosiologi dan Antropologi Fakultas Ilmu Sosial Universitas Negeri Semarang.

Farisanu, I. K. (2017). Akuntansi Koperasi. Manajemen Koperasi.

Fatimah, \& Darna. (2011). Peranan Koperasi Dalam Mendukung Permodalan Usaha Kecil dan Mikro (UKM). Jurnal Ekonomi dan Bisnis.

Hendar. (2013). Manajemen Perusahaan Koperasi. Jakarta : Erlangga.

Heriyono. (2012). Peran Koperasi Dalam Pengembangan Perekonomian Rakyat. Jurnal EKONOMI.

Hosekini, H. (2015). Analisis Faktor-Faktor Yang Mempengaruhi Sisa Hasil Usaha Koperasi Simpan Pinjam Di Kabupaten Sukoharjo. Universitas Muhammadiyah Surakarta.

Ismail, A., Sulur, A. H., Akib, H., \& Salam, R. (2016). Snapshot of Society Social-Economic Welfare based on Human Development Index in Polewali Mandar Regency, Indonesia. International Conference on Public Organization VI (ICONPO VI), 847-858.

Nainggolan, K., Parulian, T., \& Siregar, A. U. (2016). Indikator Membangun Good Cooperative Governance, untuk Menumbuhkan Kepercayaan Masyarakat terhadap Koperasi, Studi di Kota Medan. Jurnal Aplikasi Manajemen, 14(2), 334-343.

Nanga, M. (2001). Makro Ekonomi Teori, Masalah, dan Kebijakan. Jakarta: Rajawali Pers.

Putri, G. G., Sunarko, B., \& Widuri, R. (2016). Analisis Pengaruh Modal Sendiri, Modal Luar, Volume Usaha, dan Perputaran Piutang Terhadap Sisa Hasil Usaha. Performance. Performance, 23(2).

Raidayani, R., Muhammad, S., \& Faisal, F. (2016). Faktor-Faktor yang Mempengaruhi Sisa Hasil Usaha (SHU) pada Koperasi di Kabupaten Aceh Barat. Jurnal Perspektif Ekonomi 
Darussalam, 2(2), 167-184.

Rohmansyah, T., \& Sudarijati, S. (2017). Pengaruh Modal Sendiri dan Modal Pinjaman Terhadap Sisa Hasil Usaha (SHU) Koperasi Kota Sukabumi. Jurnal Visionida, 3(2), 5567.

Samuda, S. J. A. (2016). Underground economy in Indonesia. Buletin Ekonomi Moneter dan Perbankan, 19(1), 39-56.

Sitio, A., \& Tamba, H. (2001). Koperasi :Teori dan Pratik. In Ekonomi.

Sudaryanti, D. S. (2017). Pengaruh Jumlah Anggota, Modal Luar dan Total Aset Terhadap Sisa Hasil Usaha (Studi Empiris pada Koperasi Simpan Pinjam di Kota Tasikmalaya). Ekspektra: Jurnal Bisnis dan Manajemen, 1(2), 156-172.

Sugiyono. (2010). Metode Penelitian Bisnis. Pendekatan Kuantitatif, kualitatif dan R \& D. Bandung: Alfabeta.

Sugiyono. (2017). Metode Kuantitatif. In Metode Penelitian Kuantitatif, Kualitatif, dan R\&D.

Susilowati, \& Maudi, E. (2018). Strategi Koperasi Karya Mandiri Dalam Memperkenalkan Product Knowledge Melalui Event Gowes Pesona Nusantara. Jurnal Komunikasi. https://doi.org/10.31294/JKOM.V9I1.3592

Tifani, T., Surdi Djatikusuma, E., \& Yunita, C. (2015). Analisis Pengaruh Modal Sendiri, Modal Luar dan Jumlah Anggota terhadap Sisa Hasil Usaha (Studi Kasus KSP Kopdit Rukun Palembang). Jurnal Sekolah Tinggi Ilmu Ekonomi Multi Data, Palembang, 1-11.

UU No 25 Tahun 1992. (1992). UU No 25 Tahun 1992. UU RI No 25 Tahun 1992 Tentang Perkoperasian. https://doi.org/10.1017/CBO9781107415324.004

Wardani, H. (2013). Peranan Dinas Koperasi Dan UKM Dalam Pemberdayaan Usaha Kecil Menengah Kota Malang (Studi Pada Dinas Koperasi Dan UKM Kota Malang). Jurnal Administrasi Publik Mahasiswa Universitas Brawijaya.

Wiyono, I. A. (2016). Pengaruh Jumlah Anggota, Jumlah Simpanan dan Volume Usaha Terhadap Sisa Hasil Usaha Koperasi pada Tingkat Kecamatan Di Kabupaten Bojonegoro. SENASPRO.

Yuliastuti, I. A. N., \& Arie, A. A. P. G. B. (2018). Faktor - Faktor Yang Mempengaruhi Sisa Hasil Usaha Koperasi di Kota Denpasar. PIRAMIDA, 14(1), 59-66. 
62 Jurnal Ilmiah Ilmu Administrasi Publik: Jurnal Pemikiran dan Penelitian Administrasi Publik Volume 10 Number 1, January- june 2020. Page 53-62 